\title{
Comparative sensitivity of six scleractinian corals to temperature and solar radiation
}

\author{
John W. Fournie*, Deborah N. Vivian, Susan H. Yee, Lee A. Courtney, \\ Mace G. Barron
}

Gulf Ecology Division, National Health and Environmental Effects Research Laboratory, US Environmental Protection Agency, 1 Sabine Island Drive, Gulf Breeze, Florida 32561, USA

\begin{abstract}
Scleractinian corals were exposed to 6 combinations of temperature and solar radiation to evaluate effects on coral bleaching, survival, and tissue surface area changes during and after exposure. A recirculating coral exposure system was coupled to a solar simulator to allow laboratory testing of 6 species of Caribbean corals (Diploria clivosa, Montastraea faveolata, Porites divaricata, Stephanocoenia intersepta, Siderastrea radians, and Siderastrea siderea). Significant bleaching occurred in all of the corals exposed to high irradiance except $S$. siderea. Elevated light levels resulted in a decrease in photochemical efficiency for all species during the exposure period, with $S$. siderea showing the smallest decrease. The most prominent reductions in photochemical efficiency occurred in $M$. faveolata and $S$. intersepta, and these species exhibited extensive tissue loss and the highest mortality. In contrast to high irradiance, high temperatures significantly decreased photochemical efficiency for only D. clivosa and did not lead to severe tissue loss for this species. These results demonstrate species-specific responses to solar radiation and temperatures, with $M$. faveolata and $S$. intersepta being the most susceptible to bleaching due to high irradiance.
\end{abstract}

KEY WORDS: Corals $\cdot$ Bleaching $\cdot$ Temperature $\cdot$ Solar radiation

\section{INTRODUCTION}

Coral reef ecosystems have experienced significant mortalities throughout the world over the last $30 \mathrm{yr}$, and much of this decline is attributed to mass bleaching events (Hoegh-Guldberg 1999, Hughes et al. 2003, Obura 2005). Bleaching is a whitening of corals resulting from the partial or total elimination of the symbiotic zooxanthellae and/or degradation of their pigments (Fitt et al. 2001, Douglas 2003). Sustained elevated sea temperatures during the warmest months of the year have been implicated as a primary cause of mass bleaching (Glynn 1984). This is supported by a number of field and laboratory studies (e.g. Hoegh-Guldberg \& Smith 1989, Jokiel \& Coles 1990, Lesser et al. 1990, Lesser 1997, Hoegh-Guld- berg 1999) on bleaching in corals and other symbiotic cnidarians that have established a causal link between temperature stress and bleaching.

Another common factor involved in coral bleaching is high solar irradiance. Both field and laboratory studies have implicated solar radiation (SR), more specifically ultraviolet radiation (UVR) (280 to $400 \mathrm{~nm}$ ), as a cause of bleaching of reef corals. Gleason \& Wellington (1993) demonstrated that, in field experiments with Montastraea annularis, UV-induced bleaching happens rapidly and can occur in the absence of raised seawater temperatures. Recently, Ferrier-Pagès et al. (2007) reported that increased solar radiation alone significantly decreased the photochemical efficiency of 4 scleractinian coral species in laboratory experiments, even at the low temperature of $27^{\circ} \mathrm{C}$. 
High solar irradiance is also known to exacerbate temperature-induced bleaching. Laboratory studies by Lesser et al. (1990) in coral reef anthozoans and Glynn et al. (1992) in reef-building corals demonstrated a synergistic effect between temperature and irradiance. Several field studies also report similar findings (e.g. Brown \& Suharsono 1990, Brown et al. 1995). Although examples do exist of single stressors causing bleaching, bleaching of corals in shallow waters is most likely induced as a combination of both elevated temperature and high irradiance (Brown 1997, Lesser \& Farrell 2004).

Bleaching events are typically short-term phenomena, lasting only days to a few weeks, and the consequences of short-term bleaching on long-term coral growth and survival are not well understood, although there are a limited number of species whose post-bleaching fates are well-documented (Baird \& Marshall 2002). Laboratory studies evaluating the effects of elevated temperature and irradiance typically quantify photosynthetic activity during bleaching exposures but rarely look at the consequences for survival and growth rates. Furthermore, species may vary in their bleaching sensitivities to both temperature and solar radiation (Yee et al. 2008), so differential impacts on coral growth and survival have the potential to alter community dynamics (Loya et al. 2001).

We designed the present study to evaluate the role of high temperature and irradiance on bleaching, survival, and recovery among 6 species of scleractinian corals under experimental conditions to isolate effects of these environmental factors on corals. The specific objectives of the present study are (1) to investigate if temperature or irradiance alone would cause bleaching in 6 coral species and whether there is a synergistic effect for these 2 stressors and (2) to estimate changes in tissue growth during a recovery period following bleaching.

\section{MATERIALS AND METHODS}

\section{Sample collection and acclimation}

Coral specimens were collected in January 2006 from the Florida Keys National Marine Sanctuary, FL, USA, and shipped to the Gulf Ecology Division's Coral Research Laboratory, Gulf Breeze, FL. The specimens collected included Diploria clivosa, Montastaraea faveolata, Porites divaricata, Stephanocoenia intersepta, Siderastrea radians, and S. siderea. Upon arrival, coral specimens were placed into closed re-circulating culture systems containing filtered offshore seawater for acclimation. The culture systems consisted of $183 \times 122 \times 43 \mathrm{~cm}$ fiberglass tanks with overhead $400 \mathrm{~W}$ halide lamps (photosynthetically active radiation $[\mathrm{PAR}]=20.1 \mathrm{~W} \mathrm{~m}^{-2}$; UVR $=$ $0.97 \mathrm{~W} \mathrm{~m}^{-2}$ ). During the acclimation period (January 2006 to May 2007), the ammonia, nitrite, nitrate, and phosphate levels were measured using a $\mathrm{HACH}$ colorimeter (DR/890) (Table 1). Calcium levels were measured with a Pinpoint ${ }^{\mathrm{TM}}$ calcium monitor to maintain optimum levels for growth.

\section{Test apparatus and exposure}

An experimental system described by Barron et al. (2010) was used for temperature and SR exposures. This system design provided multiple small test chambers (1.2 $\mathrm{l}^{2}$ Rubbermaid ${ }^{\mathrm{TM}}$ containers), which were held in a water bath. Water surrounded the chambers to aid in minimizing temperature fluctuations. Temperature-controlled, recirculating filtered offshore seawater (36 ppt) was distributed to each test chamber via a manifold system. The manifolds received water from a sump with digital temperature control $\left( \pm 0.5^{\circ} \mathrm{C}\right)$ using a combination of 2 chillers and 3 heaters. Temperature was monitored continuously using a temperature data logger (Model TB132$05+37$, Onset). The same water quality parameters were measured as described above for acclimation.

The test chambers and water bath were located within a specular aluminum-lined light chamber capable of providing controlled lighting with 3 halide (175 W), 10 fluorescent (165 W) and 8 UVA (100 W) bulbs. Corals were exposed to a $12 \mathrm{~h}$ photoperiod with a light regime of $12 \mathrm{~h} \mathrm{~d}^{-1}$ halide, $10 \mathrm{~h} \mathrm{~d}^{-1}$ fluorescent, and $8 \mathrm{~h} \mathrm{~d}^{-1}$ UVR. Light exposure intensity was controlled using various filtering combinations

Table 1. Average parameter measurements for the culture systems (January 2006 to May 2007) and the solar simulator (May 2007). PAR: photosynthetically active radiation; UVR: ultraviolet radiation

\begin{tabular}{|lcc|}
\hline Parameter & Culture & Solar simulator \\
\hline Ammonia $\left(\mathrm{mg} \mathrm{l}^{-1}\right)$ & 0 & 0 \\
Nitrate $\left(\mathrm{mg} \mathrm{l}^{-1}\right)$ & 0.05 & 0 \\
Nitrite $\left(\mathrm{mg} \mathrm{l}^{-1}\right)$ & 0.02 & 0.01 \\
Phosphate $\left(\mathrm{mg} \mathrm{l}^{-1}\right)$ & 0.04 & 0 \\
Calcium (ppm) & 408 & 417 \\
pH & 8.12 & 8.07 \\
PAR (W m $\left.{ }^{-2}\right)$ & 20.1 & 13 (low)/72 (high) \\
UVR (W m & \\
& 0.97 & 3.8 (low) $/ 25.9$ (high) \\
\hline
\end{tabular}


(acrylic filters and dark plastic mesh) at the test chamber level to achieve an appropriate reduction in light intensity from the ambient level in the light chamber. For additional details regarding system design, see Barron et al. (2010). A MACAM radiometer and spectroradiometer (OL 752-10 Optronics) were used to measure the intensity of UVR (280 to $400 \mathrm{~nm}$ ) and visible (400 to $800 \mathrm{~nm}$ ) light levels both before and after testing.

Coral specimens were cut into fragments $2 \mathrm{wk}$ prior to testing (May 2007). Although the use of coral fragments from a limited number of colonies in a laboratory study limits the ability to generalize to species differences that may occur in nature, it provides a mechanism for increasing the number of replicates and reducing variability among treatments (Shafir et al. 2003). Non-branching coral specimens were cut into $\sim 2.5 \mathrm{~cm}$ squares using a wet saw with a $25.4 \mathrm{~cm}$ jeweler's diamond blade. The one branched species, Porites divaricata, was cut into $\sim 1.3 \mathrm{~cm}$ high fragments using bone cutters. All fragments were mounted on clear Plexiglass ${ }^{\circledR}$ pedestals. One specimen of each coral species was placed in each test chamber $(6$ corals per test chamber), and the test chambers were randomly distributed in the light chamber's water bath. The exposure treatments included the following: control temperature $25^{\circ} \mathrm{C}$, low $\mathrm{SR}$ (visible $=12.95$; $\mathrm{SR}=3.75 \mathrm{~W} \mathrm{~m}^{-2}$ ); control temperature $25^{\circ} \mathrm{C}$, mid SR (visible $=40.66 ; \mathrm{SR}=13.86 \mathrm{~W} \mathrm{~m}^{-2}$ ); control temperature $25^{\circ} \mathrm{C}$, high SR (visible $=72.19 ; \mathrm{SR}=25.85 \mathrm{~W} \mathrm{~m}^{-2}$ ); high temperature $31^{\circ} \mathrm{C}$, low $\mathrm{SR}_{\text {; }}$ high temperature $31^{\circ} \mathrm{C}$, mid SR; high temperature $31^{\circ} \mathrm{C}$, high SR. Light levels were chosen to simulate those recorded at various depths in the Florida Keys (Barron et al. 2009). Each treatment had 3 replications, and a total of 108 coral specimens were tested. Exposures to the experimental treatments were conducted for $10 \mathrm{~d}$, after which corals were transferred to and maintained in the coral culture system for a $40 \mathrm{~d}$ recovery period. Corals were not fed during the $10 \mathrm{~d}$ exposure period.

\section{Photochemical efficiency}

Pulse amplitude modulation (PAM) fluorometry was used to monitor the photochemical efficiency of zooxanthellae both during and after exposures. Coral specimens were dark adapted for $30 \mathrm{~min}$ and measured in situ using a diving PAM (Waltz-Heinz). The fiber optic probe was placed $\sim 3 \mathrm{~cm}$ above the coral tissue, and a photosynthetic yield (Fv/Fm) was recorded for each coral specimen (Genty et al. 1989). Measurements were conducted once before expo- sure, daily during the exposure, and weekly for the duration of the recovery period. The photochemical efficiency for each coral specimen during exposure and recovery was calculated as the difference relative to pre-exposure values.

\section{Measurement of tissue area and visual observations}

Change in the amount of live tissue was assessed by a comparison of photographic images from the start to end of recovery. Photographs were taken of all 4 sides ( $90^{\circ}$ rotation) of each coral specimen biweekly. Standardization for focal distance and camera position for each image was accomplished using a jig system with a rotating stage. The photographs were processed in a commercially available photographic image processing software (Adobe ${ }^{\circledR}$ Photoshop ${ }^{\circledR}$ CS3 version 10.0, C 1990-2007 Adobe ${ }^{\circledR}$ Systems) to produce a mask of the live tissue area for each view at each time point (Fig. 1); photographs from the initial time point were used to register (align and size) all subsequent images. Black masks representing the live tissue were exported as grayscale images for each view and time point. These images were analyzed to produce surface area values $\left(\mathrm{mm}^{2}\right)$ using ImageJ software (ImageJ 1.38x, Wayne Rasband, National Institutes of Health, Bethesda, MD USA; http://rsb.info.nih.gov/ $\mathrm{ij} /$ ). Data from all sides were summed for each specimen to produce a total surface area for analysis. The summation of the 4 sides has been correlated to the actual 3D surface area via a laser scanner (D. N. Vivian et al. unpubl.). Tissue change was estimated as the difference in surface area during the experiment relative to pre-exposure values. Additional visual assessments of the corals for bleaching were made at the start and end of the exposure period and at the end of the recovery period.

\section{Statistical analyses}

The effects of light and temperature were evaluated for visible bleaching at the end of exposure and mortality at the end of the experiment using analyses of variance (ANOVA) for a split plot design, with a container (plot) containing a single specimen for each species and 3 replicate containers per treatment. A repeated-measures analysis of variance (rmANOVA) for a split-plot design was used to assess differences among species in the relative change in photochemical efficiency during the exposure 


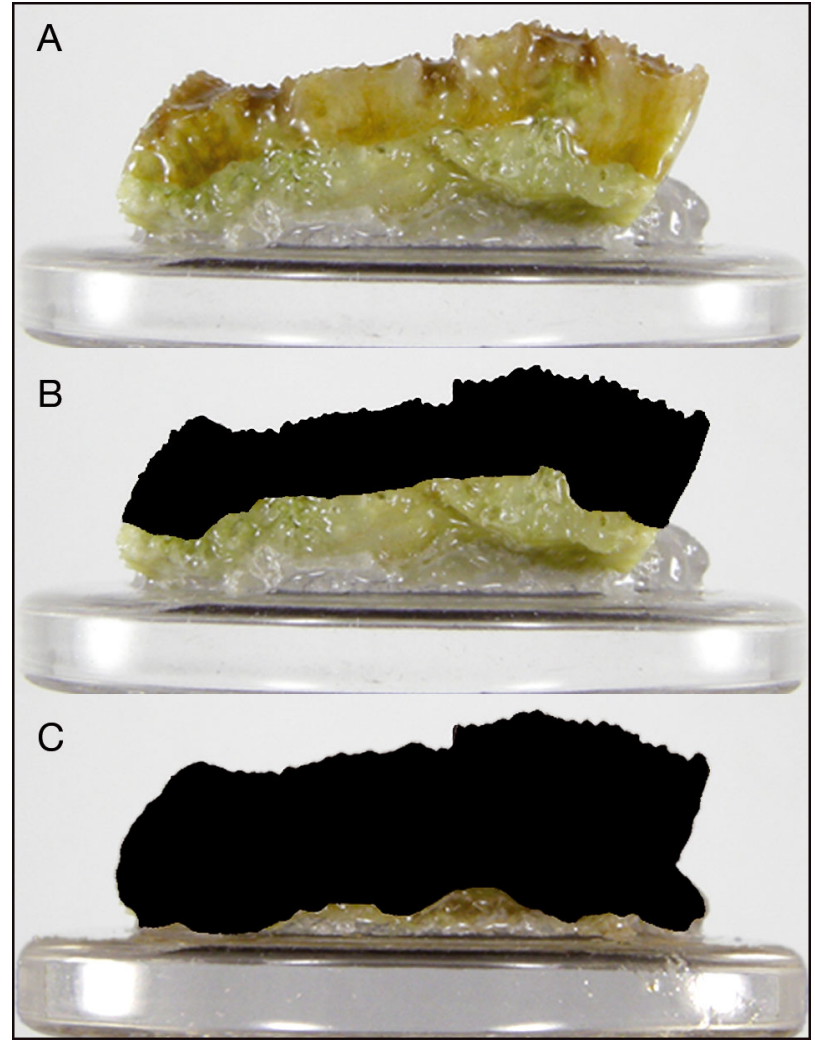

Fig. 1. Example of 2D tissue area analysis method shows Montastraea faveolata at test start (A) without and (B) with tissue mask and (C) tissue mask at end of test. Difference in mask area between time points is used to calculate change in tissue cover

period. The photochemical efficiency during the recovery period and change in surface area during recovery were also analyzed in separate rm-ANOVAs. Dead specimens were considered to have a decrease in photochemical efficiency or tissue of $100 \%$; analyses with dead specimens were compared to analyses in which dead specimens were excluded. We compared means among treatment levels using $t$-tests for between-subjects effects and paired $t$-tests for within-subjects effects, with a Bonferroni sequential adjustment of the $p$ values. Statistical analyses were performed using function 'lme' in the statistical package $\mathrm{R}$ (www.r-project.org) using an $\alpha$ of 0.1 because of low sample sizes.

\section{RESULTS}

\section{Observations of bleaching}

High irradiance during experimental exposures had a significant effect on observed bleaching for all species except Siderastrea siderea (Species $\times \mathrm{SR}, F=$ 5.53, $\mathrm{p}<0.001$; paired $t$-test, Bonferroni adjusted [adj]. $\mathrm{p}=1.00$ for $S$. siderea in low- or mid- vs. highlevel irradiance, $\mathrm{p}<0.01$ for all other species) (Fig. 2). Irradiance effects were consistent across temperatures (Temperature $\times \mathrm{SR}, F=1.66, \mathrm{p}=0.23$; Temperature $\times$ Species $\times \mathrm{SR}, F=0.51, \mathrm{p}=0.88$ ), and there were no significant effects of temperature on observed bleaching for any species (Temperature, $F=$ 0.16, $\mathrm{p}=0.70$; Species $\times$ Temperature, $F=0.99, \mathrm{p}=$ 0.43). By the end of the recovery period, all corals appeared to have returned to normal pigmentation, with the exception of those coral specimens that died.

\section{Photochemical efficiency}

Observations of bleaching under high irradiance corresponded to reductions in photochemical efficiency for most species during the exposure period (Fig. 3). Mid- and high-level irradiance significantly reduced the photochemical efficiency of all species, with high irradiance leading to significantly greater reductions than mid-level irradiance for all species except Siderastrea siderea (SR, $F=53.9, \mathrm{p}<0.001$; SR $\times$ Species, $F=1.95, \mathrm{p}=0.056$; paired $t$-test, Bonferroni adj. $\mathrm{p}=0.178$ for $S$. siderea, mid vs. high irradiance, $\mathrm{p}<0.05$ for all other species). The greatest reductions in photochemical efficiency due to higher irradiance were for Diploria clivosa, Montastraea faveolata, and

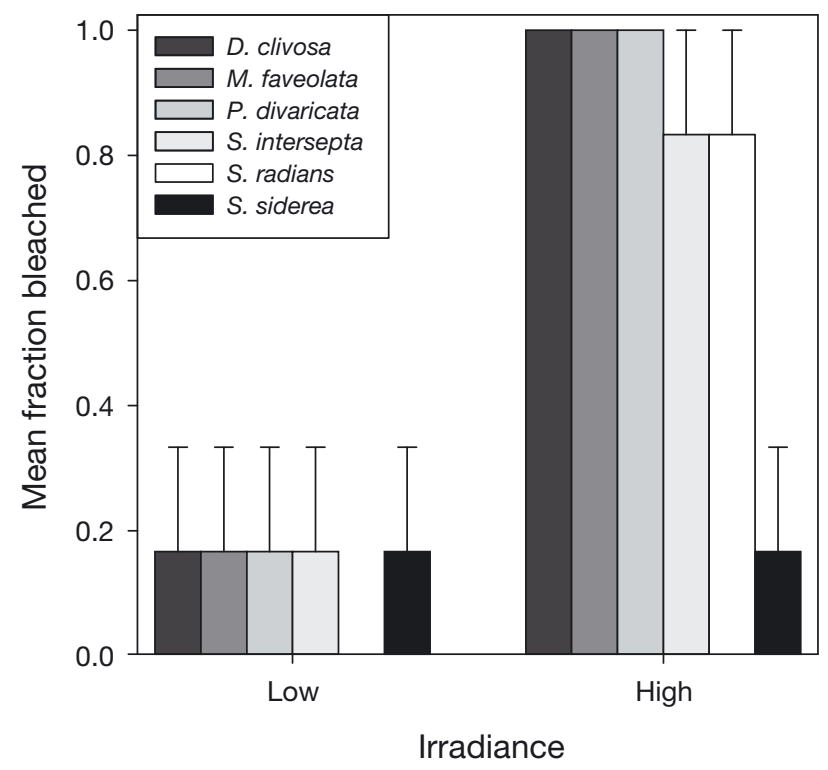

Fig. 2. Mean (+1 SE) fraction bleached for 6 corals exposed to 3 levels of irradiance (low, mid, and high). Mean fractions bleached for mid-level light treatments were equal to 0 and are not shown. See Fig. 3 for full species names 

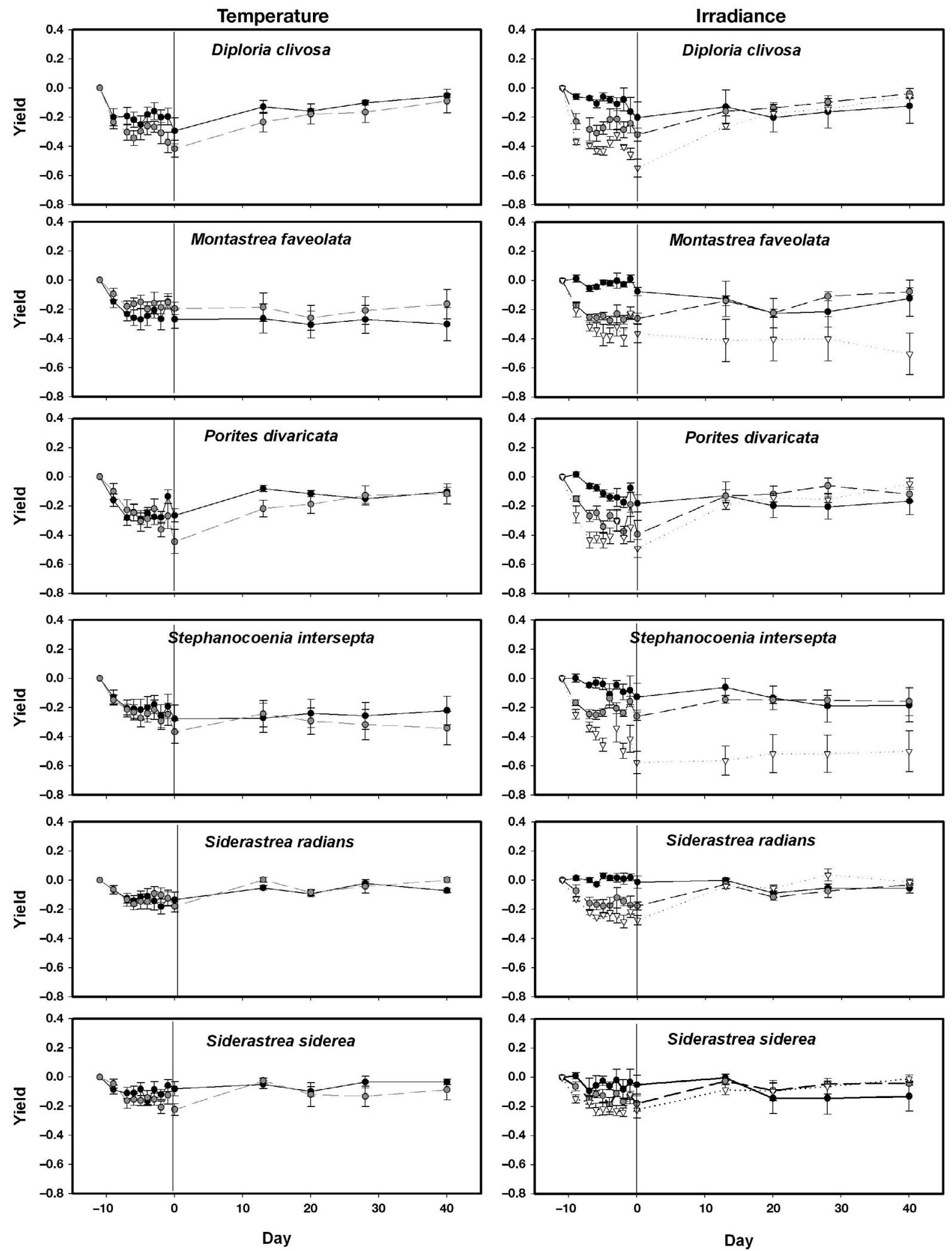

Fig. 3. Average change in photosynthetic efficiency ( $\pm 1 \mathrm{SE})$ of 6 corals exposed to a range of temperatures (left panels) and

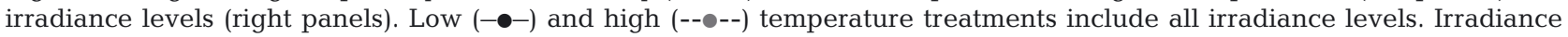

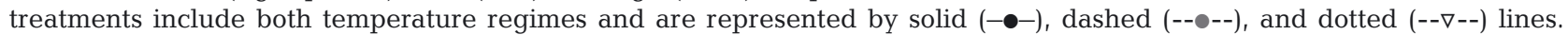
Vertical line separates exposure and recovery periods 
Porites divaricata, which had significantly lower levels than either $S$. siderea or $S$. radians under both mid- and high-level irradiance (paired $t$-test, Bonferroni adj. $\mathrm{p}<0.001$ for indicated species pairs under mid- or high-irradiance). Although not manifested as observable bleaching, high temperatures significantly decreased photochemical efficiency for $D$. clivosa but had no significant effect on photochemical efficiency for the other 5 species (Temp $\times$ Species, $F=3.08, \mathrm{p}=$ 0.015 ; paired $t$-test, Bonferroni adj. $\mathrm{p}=0.05$ for $D$. clivosa under low vs. high temperatures). The effects of temperature were consistent among light levels, i.e. the effects of high temperature were not further exaggerated by high irradiance $($ Temp $\times \mathrm{SR}, F=1.49, \mathrm{p}=$ $0.263)$. Photochemical efficiency was significantly different between low-, mid-, and high-level irradiance treatments on the first day of exposure and declined significantly further on the second day for both midand high-level irradiance (SR $\times$ Day, $F=1.58, \mathrm{p}=0.07$; paired $t$-test, Bonferroni adj. $\mathrm{p}<0.001$ for the second day compared to the first day of exposure). Similarly, the photochemical efficiency declined significantly between the first and second days of exposure under both temperature treatments, but for high temperature treatments, the efficiency remained significantly low throughout the exposure period $($ Temp $\times$ Day, $F=$ 3.62, $\mathrm{p}<0.001$; paired $t$-test, Bonferroni adj. $\mathrm{p}<0.07$ for all days compared to the first day of exposure). Overall, exposure treatments reduced photochemical efficiency most severely for $P$. divaricata, which experienced a significant reduction between the first and last days of exposure (Species $\times$ Day, $F=1.56, \mathrm{p}=$ 0.017; paired $t$-test, Bonferroni adj. $\mathrm{p}=0.034$ ).

Most species returned to pre-exposure levels of photochemical efficiency during the recovery period when colonies were removed from exposure and returned to culture (Fig. 3). For Diploria clivosa, photochemical efficiency levels, which had been reduced under high temperature exposure, steadily increased in recovery $($ Temp $\times$ Species $\times$ Day, $F=$ 2.45, $\mathrm{p}=0.003$; paired $t$-test, Bonferroni adj. $\mathrm{p}<0.1$ for Day 28 or 40 of recovery compared to Day 20) and were not significantly different between temperature treatments (paired t-test, Bonferroni adj. p > 0.1 for low vs. high temperatures for each day in recovery). Similarly, reductions in photochemical efficiency under high irradiance treatments were still present after $13 \mathrm{~d}$ of recovery, but overall did not persist to the end of recovery $(\mathrm{SR} \times$ Day, $F=$ 7.21, $\mathrm{p}<0.001$; paired $t$-test Bonferroni adj. $\mathrm{p}<0.1$ for low- or mid- vs. high light on Day 13, p > 0.1 for all other days). However, Montastraea faveolata and Stephanocoenia intersepta exposed to high irradi- ance treatments had significant reductions in photochemical efficiency that persisted throughout recovery $(\mathrm{SR} \times$ Species, $F=3.99, \mathrm{p}<0.001$; paired $t$-test, Bonferroni adj. $\mathrm{p}=0.083$ for $M$. faveolata in mid- vs. high irradiance, $\mathrm{p}<0.05$ for $S$. intersepta in low- or mid- vs. high irradiance).

\section{Mortality and tissue loss}

High irradiance levels also led to significant mortality for Montastraea faveolata (Species $\times \mathrm{SR}, F=$ 4.71, $\mathrm{p}=0.001$; paired $t$-test, Bonferroni adj. $\mathrm{p}=0.023$ under mid- vs. high-level irradiance). M. faveolata exhibited high mortality rates, with $67 \%$ of corals exposed to the highest SR treatment dying during the recovery period. Irradiance effects on mortality were consistent across temperatures (Temperature $\times$ SR, $F=1.23, \mathrm{p}=0.33$; Temperature $\times$ Species $\times \mathrm{SR}, F=$ $1.21, \mathrm{p}=0.30$ ), and temperature did not significantly affect mortality (Temperature, $F=0.53, \mathrm{p}=0.48$; Species $\times$ Temperature, $F=1.33, \mathrm{p}=0.26)$. The reductions in photochemical efficiency were upheld even when dead individuals were excluded from analyses.

High irradiance significantly affected tissue surface area for Stephanocoenia intersepta and Montastraea faveolata during recovery ( $\mathrm{SR} \times$ Species, $F=$ 3.37, $\mathrm{p}=0.002$; Fig. 4). These 2 species experienced severe tissue loss and death during recovery following high irradiance exposures (paired $t$-test, Bonferroni adj. $\mathrm{p}=0.002$ for $M$. faveolata in mid- vs. high irradiance, $\mathrm{p}<0.001$ for $S$. intersepta in low- or midvs. high irradiance). For the other 4 species, tissue surface area changes were similar among all light treatments during recovery. Irradiance effects on tissue change were consistent across temperatures (Temperature $\times \mathrm{SR}, F=0.60, \mathrm{p}=0.56$; Temperature $\times$ Species $\times \mathrm{SR}, F=0.602, \mathrm{p}=0.81$ ), and temperature did not significantly affect mortality (Temperature, $F=0.53, \mathrm{p}=0.48$; Species $\times$ Temperature, $F=1.33, \mathrm{p}=$ $0.2625)$. In contrast to high irradiance, the significant reductions in photochemical efficiency for Diploria clivosa under high temperature exposure did not precipitate severe tissue loss for this species (Temperature, $F=0.25, \mathrm{p}=0.62$; Temperature $\times$ Species, $F=$ 2.16, $\mathrm{p}=0.07$ ). However, $S$. intersepta experienced significant reductions in tissue area under high temperatures (paired $t$-test, Bonferroni adj. $\mathrm{p}<0.02$ for each species compared to $S$. intersepta under high temperatures), despite no significant effect of temperature on photochemical efficiency. By the end of recovery, $S$. intersepta had significantly higher tissue loss than either Porites divaricata or Siderastrea radi- 


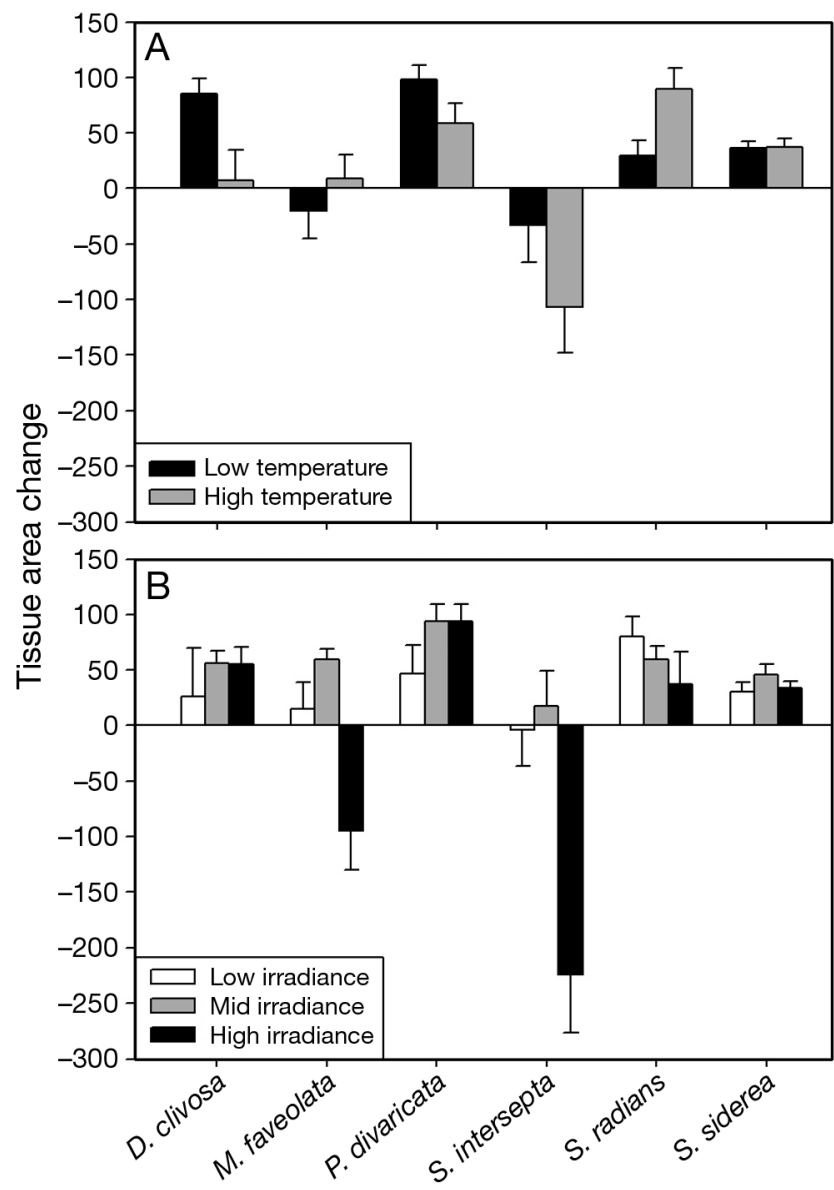

Fig. 4. Average change in tissue area $( \pm 1 \mathrm{SE})$ for the recovery period. (A) Low (black bars) and high (gray bars) temperature treatments include all irradiance levels. (B) Low (white bars), mid (gray bars), and high (black bars) irradiance treatments include both temperature regimes. See

Fig. 3 for full species names

ans (Species $\times$ Day, $F=6.27, \mathrm{p}<0.001$; paired $t$-test, Bonferroni adj. $\mathrm{p}<0.03$ for indicated species pairs on Day 39 of recovery).

\section{DISCUSSION}

Numerous studies from both the laboratory and field have shown that a variety of reef corals bleach when exposed to elevated seawater temperatures (e.g. Hoegh-Guldberg \& Smith 1989, Lesser et al. 1990, Glynn \& D'Croz 1990, Hoegh-Guldberg 1999), high solar irradiance (e.g. Gleason \& Wellington 1993), or a combination of both stressors (e.g. Glynn et al. 1992). The primary cause of bleaching among the 6 species within the temperature and irradiance ranges we tested was high irradiance, and no interaction was observed between temperature and solar radiation. Even though zooxanthellae and pigment concentrations were not measured, bleaching did occur, as evidenced by observable reductions in visible pigmentation as well as reductions in photochemical efficiency both during and after exposure. All species exposed to high irradiance showed a significant decline in photochemical efficiency for the length of the exposure period, with Montastraea faveolata and Stephanocoenia intersepta showing the most severe decline resulting in severe tissue loss and mortality. Both field and laboratory studies have shown that solar radiation alone can cause bleaching of reef corals. Gleason \& Wellington (1993) demonstrated that in field experiments with Montastraea annularis, UV-induced bleaching occurs rapidly and can occur in the absence of elevated seawater temperatures. In laboratory studies, Ferrier-Pagès et al. (2007) reported that increased solar radiation significantly decreased the photochemical efficiency of 4 scleractinian corals, even at $27^{\circ} \mathrm{C}$. Our results corroborate that under certain conditions, bleaching can be caused by high irradiance alone.

In contrast to high solar irradiance, we found only minor effects of elevated temperatures on coral bleaching within the examined thermal range. No species exhibited significant observable reductions in pigmentation under elevated temperatures alone; only the high irradiance treatments had significantly observable bleaching. Reductions in photochemical efficiency under elevated temperatures were significant for only one species, Diploria clivosa, and recovered to normal levels upon return to culture conditions. This species is known to be thermally sensitive to bleaching at different locations in the Florida Keys (Wagner et al. 2010). The range of temperatures and test duration in these studies were comparable to other laboratory studies (Glynn \& D'Croz 1990, Middlebrook et al. 2008, Ferrier-Pagès et al. 2007, 2010). It is not known whether a longer test period could have resulted in significant temperature effects for other species.

This is the first laboratory bleaching study to utilize Stephanocoenia intersepta and to demonstrate its apparent susceptibility to high irradiance. However, conflicting reports exist from field studies regarding the susceptibility of $S$. intersepta to bleaching. Brandt (2009) indicated that $S$. intersepta was one of the most tolerant coral species in the Florida Keys based on data collected after major bleaching events. In contrast, Clark et al. (2009) found S. intersepta to be relatively susceptible to bleaching in St. Croix. These discrepancies between studies may reflect differences in survey scale or frequency, or they may 
reflect differences in the physiology of the corals or their symbiont populations (Brandt 2009). Our laboratory study supports the findings of Clark et al. (2009) to indicate that $S$. intersepta is vulnerable to bleaching from high irradiance.

Siderastrea siderea appeared most resistant to bleaching when exposed to high irradiance in our laboratory tests, exhibiting little observable bleaching and the weakest decrease in photochemical efficiency during the exposure period compared to other species. The $S$. siderea colonies remained healthy, showing no signs of bleaching or any other disease. This species has shown little response to elevated solar radiation in field studies as well (Yee et al. 2008). This is not entirely unexpected because a closely related species, $S$. radians, is considered to be one of the most stress-tolerant coral species in the Caribbean (Lewis 1989). In our experiments, S. radians also exhibited only small reductions in photochemical efficiency under high irradiance and fully recovered upon return to culture conditions. The resistance and resilience of $S$. radians to stress was more recently reported by Lirman et al. (2002). They demonstrated that colonies originally classified as dead after prolonged exposure to low salinity and sediment burial recovered completely after being returned to ambient conditions. This remarkable resilience was attributed to remnant tissue surviving deep within the coral structure that allowed the colonies to recover (Lirman et al. 2002).

Few laboratory studies have examined recovery from bleaching induced by a combination of high solar radiation and elevated temperatures, and none have compared responses of different species (Fitt \& Warner 1995, Ferrier-Pagès et al. 2007). We found that most species recovered from bleaching, evidenced by a return to normal pigmentation, a gradual increase in photochemical efficiency towards pre-exposure levels, and an increase in the amount of tissue growth. Only Montastraea faveolata and Stephanocoenia intersepta showed a significant loss of tissue, a persistent reduction in photochemical efficiency, and mortality after exposure to high irradiance. The 2D method quantified these changes in tissue area during the recovery period. The 2D method was an effective, non-destructive technique for evaluating changes in tissue area as a result of exposure to various stressors.

Knowledge of species-specific susceptibility to bleaching is increasing with field (Loya et al. 2001, Yee et al. 2008) and laboratory studies (Ferrier-Pagès et al. 2007). For some species, reductions in photosynthetic ability or tissue growth during a bleaching event are quickly reversed upon return to normal environmental conditions. Other species, however, may experience severe tissue loss and mortality. The 2 species most vulnerable to high irradiance, Montastraea faveolata and Stephanocoenia intersepta, were not the species most vulnerable to elevated temperatures. These species-specific differences in susceptibility may have long-term consequences for the species composition of the community, particular as temperature and UV events increase in intensity and frequency (Loya et al. 2001). Laboratory studies contribute to our understanding of bleaching and may help identify species that are particularly susceptible to stressful environmental conditions.

Acknowledgements. We thank L. MacLaughlin at the Florida Keys National Marine Sanctuary and D. Santavy at the Gulf Ecology Division for coral collection (Permit \#FKNMS-2004-001). The information in this document has been funded wholly by the USA Environmental Protection Agency. It has been subjected to review by the National Health and Environmental Effects Research Laboratory and approved for publication. Approval does not signify that the contents reflect the views of the Agency, nor does mention of trade names or commercial products constitute endorsement or recommendation for use. This is contribution number 1435 from the Gulf Ecology Division.

\section{LITERATURE CITED}

Baird AH, Marshall PA (2002) Mortality, growth and reproduction in scleractinian corals following bleaching on the Great Barrier Reef. Mar Ecol Prog Ser 237:133-141

Barron MG, Vivian DN, Yee SH, Santavy DL (2009) Methods to estimate solar radiation dosimetry in coral reefs using remote sensed, modeled, and in situ data. Environ Monit Assess 151:445-455

Barron MG, McGill CJ, Courtney LA, Marcovich DT (2010) Experimental bleaching of a reef building coral using a simplified recirculating laboratory exposure system. J Mar Biol 2010:1-8

Brandt ME (2009) The effect of species and colony size on the bleaching response of reef-building corals in the Florida Keys during the 2005 mass bleaching event. Coral Reefs 28:911-924

> Brown BE, Suharsono (1990) Damage and recovery of coral reefs affected by El Niño related seawater warming in the thousand islands, Indonesia. Coral Reefs 8:163-170

Brown BE (1997) Coral bleaching: causes and consequences. Coral Reefs 16(Suppl):S129-S138

$>$ Brown BE, Le Tissier MDA, Bythell JC (1995) Mechanisms of bleaching from histological studies of reef corals sampled during a natural bleaching event. Mar Biol 122: 655-663

Clark R, Jeffrey C, Woody K, Hillis-Starr Z, Monaco M (2009) Spatial and temporal patterns of coral bleaching around Buck Island and Reef National Monument, St. Croix, U.S. Virgin Islands. Bull Mar Sci 84:167-182

$>$ Douglas AE (2003) Coral bleaching - how and why? Mar Pollut Bull 46:385-392 
Ferrier-Pagès C, Richard C, Forcioli D, Allemand D, Pichon M, Shick JM (2007) Effects of temperature and UV radiation increases on the photosynthetic efficiency in four scleractinian coral species. Biol Bull 213:76-87

Ferrier-Pagès C, Rottier C, Beraud E, Levy O (2010) Experimental assessment of the feeding effort of three scleractinian coral species during a thermal stress: effect on the rates of photosynthesis. J Exp Mar Biol Ecol 390:118-124

Fitt WK, Warner ME (1995) Bleaching patterns of four species of Caribbean reef corals. Biol Bull 189:298-307

Fitt WK, Brown BE, Warner ME, Dunne RP (2001) Coral bleaching: interpretation of thermal tolerance limits and thermal thresholds in tropical corals. Coral Reefs 20: $51-65$

Genty B, Briantais J, Baker NR (1989) The relationship between the quantum yield of photosynthetic electron transport and quenching of chlorophyll fluorescence. Biochim Biophys Acta 990:87-92

Gleason DF, Wellington GM (1993) Ultraviolet radiation and coral bleaching. Nature 365:836-838

Glynn PW (1984) Widespread coral mortality and the 1982/83 El Niño warming event. Environ Conserv 11: 133-146

Glynn PW, D'Croz L (1990) Experimental evidence for high temperature stress as the cause of El Niño-coincident coral mortality. Coral Reefs 8:181-191

Glynn PW, Imai R, Sakai K, Nakano Y, Yamazato K (1992) Experimental responses of Okinawan (Ryukyu Islands, Japan) reef corals to high sea temperature and UV radiation. Proc 7th Int Coral Reef Symp, Guam 1:27-37

Hoegh-Guldberg O (1999) Climate change, coral bleaching and the future of the world's coral reefs. Mar Freshw Res 50:839-866

Hoegh-Guldberg O, Smith GJ (1989) The effect of sudden changes in temperature, light and salinity on the population density and export of zooxanthellae from the reef corals Stylophora pistillata Esper and Seriatopora hystrix Dana. J Exp Mar Biol Ecol 129:279-303

Hughes TP, Baird AH, Bellwood DR, Card M and others (2003) Climate change, human impacts, and the resilience of coral reefs. Science 301:929-933

Editorial responsibility: Garriet Smith,

Aiken, South Carolina, USA
Jokiel PL, Coles SL (1990) Responses of Hawaiian and other Indo-Pacific reef corals to elevated temperatures. Coral Reefs 8:155-162

- Lesser MP (1997) Oxidative stress causes coral bleaching during exposure to elevated temperatures. Coral Reefs 16:187-192

Lesser MP, Farrell JH (2004) Exposure to solar radiation increases damage to both host tissues and algal symbionts of corals during thermal stress. Coral Reefs 23: 367-377

Lesser MP, Stochaj WR, Tapley DW, Shick JM (1990) Bleaching in coral reef anthozoans: effects of irradiance, ultraviolet radiation, and temperature on the activities of protective enzymes against active oxygen. Coral Reefs 8: $225-232$

Lewis JB (1989) Spherical growth in the Caribbean coral Siderastrea radians (Pallas) and its survival in disturbed habitats. Coral Reefs 7:161-167

Lirman D, Manzello D, Macia S (2002) Back from the dead: the resilience of Siderastrea radians to severe stress. Coral Reefs 21:291-292

> Loya Y, Sakai K, Yamazato K, Nakano Y, Sambali H, van Woesik R (2001) Coral bleaching: the winners and the losers. Ecol Lett 4:122-131

Middlebrook R, Hoegh-Guldberg O, Leggat W (2008) The effect of thermal history on the susceptibility of reefbuilding corals to thermal stress. J Exp Biol 211: 1050-1056

Obura D (2005) Resilience and climate change: lessons from coral reefs and bleaching in the Western Indian Ocean. Estuar Coast Shelf Sci 63:353-372

Shafir S, Van Rijn J, Rinkevich B (2003) The use of coral nubbins in coral reef ecotoxicology testing. Biomol Eng 20: 401-406

> Wagner DE, Kramer P, van Woesik R (2010) Species composition, habitat, and water quality influence coral bleaching in southern Florida. Mar Ecol Prog Ser 408:65-78

> Yee SH, Santavy DL, Barron MG (2008) Comparing environmental influences on coral bleaching across and within species using clustered binomial regression. Ecol Model 218:162-174

Submitted: September 8, 2011; Accepted: February 24, 2012 Proofs received from author(s): May 14, 2012 